\title{
Surgical management of an extra gastrointestinal tumor (EGIST) of unspecified etiology, with voluminous liver and peritoneal metastases - case presentation
}

\author{
Managementul chirurgical al unei tumori extra gastrointestinale (EGIST) de \\ etiologie neprecizată, cu metastaze voluminoase hepatice şi peritoneale - \\ prezentare de caz
}

\author{
Mădălina Elena Tobă ${ }^{1,2}$, Florin Dan Ungureanul, ${ }^{1,2}$, Cosmin Moldovan ${ }^{1,2}$ \\ ${ }^{1}$ Spitalul Clinic CF1 Witting, Bucureşti, România \\ 2Facultatea de Medicină, Universitatea „Titu Maiorescu“, Bucureşti, România
}

\begin{abstract}
Since gastrointestinal stromal tumors (GIST) were defined as a nosological entity only at the beginning of the millennium, their exact diagnosis having a relatively short history, both in Romania and internationally, studies are still being carried out aimed at establishing the incidence or studying the course of the disease. This is all the more difficult because GISTs present themselves clinically in a multitude of forms, which can develop from the esophagus to the anus and sometimes extragastrointestinal (EGIST), and from an oncological point of view range from a small harmless tumor node to a metastatic sarcoma with vital potential. Gastrointestinal stromal tumors (GIST), soon after it was proven that the main mechanism involved in their ethiopaty is a KIT or PDFRGA mutation, became the first targets of tyrosine-kinase inhibitor (TKI) therapy, being the first solid tumors treated with Imatinib. As a rare pathology, studies carried out in the country were carried out in relatively small batches and generally analyzed the experience of a single medical center. In this context, the case of our patient with EGIST with hepatic localization but unspecified etiology, with a favorable response to combined surgical and chemotherapy treatment with Imatinib becomes even more relevant to get the attention of surgeons facing this pathology.
\end{abstract}

Keywords: tumors, extra GIST, metastases, hepatic, peritoneal

\section{REZUMAT}

Ca urmare a faptului că tumorile stromale gastrointestinale (GIST) au fost definite drept entitate nosologică de-abia la începutul mileniului, diagnosticul exact al acestora având o istorie relativ scurtă, atât în România, cât şi pe plan internațional, încă se derulează studii care au drept scop stabilirea incidenței sau studierea evoluției bolii. Acest fapt este cu atât mai dificil cu cât GIST se prezintă, din punct de vedere clinic, sub o multitudine de forme, putându-se dezvolta de la nivelul esofagului până la anus şi uneori extragastrointestinal (EGIST), iar, din punct de vedere oncologic, variază de la un mic nodul tumoral inofensiv la un sarcom metastazant cu potențial vital. Curând după ce s-a dovedit că principalul mecanism implicat în etiopatogenia acestora este o mutație KIT sau PDFRGA, tumorile stromale gastrointestinale (GIST) au devenit primele ținte ale terapiei cu inhibitori de tirozinkinază (TKI), fiind primele tumori solide tratate cu Imatinib. Fiind o patologie rară, studiile efectuate în țară au fost realizate pe loturi relativ mici şi, în general, au analizat experiența unui singur centru medical. În acest context, cazul pacientei noastre cu EGIST cu localizare hepatică şi de etiologie neprecizată, cu răspuns favorabil la tratamentul combinat chirurgical şi chimioterapic cu Imatinib, devine şi mai relevant pentru a intra în atenția chirurgilor care se confruntă cu această patologie.

Cuvinte cheie: tumori, extra GIST, metastaze, hepatice, peritoneale 


\section{INTRODUCERE}

Tumorile stromale gastrointestinale (GIST) sunt tumori subepiteliale maligne (SET) ale tractului gastrointestinal cel mai frecvent întâlnite în practica zilnică, reprezentând $80 \%$ din totalul tumorilor subepiteliale şi între 0,5 şi $3 \%$ din totalul tumorilor gastrointestinale. Acestea au fost recunoscute drept tumori distinctive din punct de vedere biologic, diferite de cele dezvoltate din celulele musculare netede sau cele provenite din creasta neurală, termenul de tumori gastrointestinale stromale (GIST) fiind propus de Mazur şi Clark în 1983 (1). Constatarea conform căreia celulele tumorale prezintă expresia membranară a CD34 ca şi celula interstițială Cajal (celulă pacemaker cu rol de coordonare a motilităţii intestinale) a condus la ipoteza originii GIST din celula Cajal sau dintr-un precursor al acesteia (2).

Tumorile stromale gastrointestinale pot fi localizate oriunde în peretele viscerelor cavitare, de la esofag la anus, şi anume $40-70 \%$ dintre acestea se dezvoltă la nivelul stomacului, $20-40 \%$ la nivelul intestinului subțire, 5\% la nivelul duodenului, $5-15 \%$ la nivelul colonului şi rectului şi, în puține cazuri, au fost descrise la nivelul esofagului, apendicelui şi vezicii biliare (3-5). Rareori, au fost raportate tumori de tip GIST care se pot dezvolta în mezenterul adiacent, epiploon, retroperitoneu şi, extrem de rar, în plămâni şi organele genitale la femeie, acestea fiind denumite extragastrointestinal GIST (EGIST) $(5,6)$. GIST descoperite la nivelul organelor parenchimatoase - ficat, pancreas, prostată sunt considerate metastatice prin extensie directă de la tumori gastrice şi duodenale sau rectale $(5,7)$.

\section{PREZENTAREA CAZULUI}

Aducem în discuție cazul clinic al unei paciente, în vârstă de 71 ani, fără antecedente personale patologice sau tratamente cronice, care se prezintă la internare în Secția Clinică Chirurgie Generală a Spitalului Clinic CF1 Witting Bucureşti pentru fatigabilitate accentuată, inapetență, scădere ponderală minoră şi creştere în volum a abdomenului.

Examenul clinic relevă pacientă palidă, astenică, cu stare generală uşor alterată, prezentând abdomen cu distensie extremă, simetrică, cu ascită în cantitate mare, în tensiune, cu tranzit intestinal păstrat şi disfuncție respiratorie de tip restrictiv. Tuşeu rectal în limite normale.

Datele de laborator pun în evidență anemie moderată microcitară, hipocromă cu $\mathrm{HGB}=8,20 \mathrm{~g} / \mathrm{d}$, HCT $=26 \%$ şi sideremie în limite normale, trombocitoză - PLT $=942 \times 10^{3} / \mathrm{mm}^{3}$, sindrom minim de citoliză hepatică - TGO $=35$ UI/l, sindrom de colestază anicterică - GGT $=395$ UI/1, FA $=499$ $\mathrm{UI} / 1$, sindrom inflamator marcat $\mathrm{cu} \mathrm{VSH}=140$ $\mathrm{mm} / \mathrm{h}$, uree $=43 \mathrm{mg} / \mathrm{dl}$. Restul testelor biologice efectuate au fost în limite normale - Ag HBS, Ac anti HVC, test de hemoragii oculte in scaun, examen coproparazitologic, test tip ELISA pentru Echinococcus granulosus - şi au fost efectuate ulterior internării ca urmare a descrierilor investigațiilor imagistice.

Examenul ecografic relevă ficat cu aspect neomogen, steatozic, care prezintă multiple formațiuni tumorale înlocuitoare de spațiu: vena portă şi calea biliară principală au dimensiuni normale şi conținut neomogen, colecistul comprimat fiind aparent alitiazic. Lichidul de ascită liber în cavitatea peritoneală apare în cantitate moderată (Figurile 1, 2, 3).

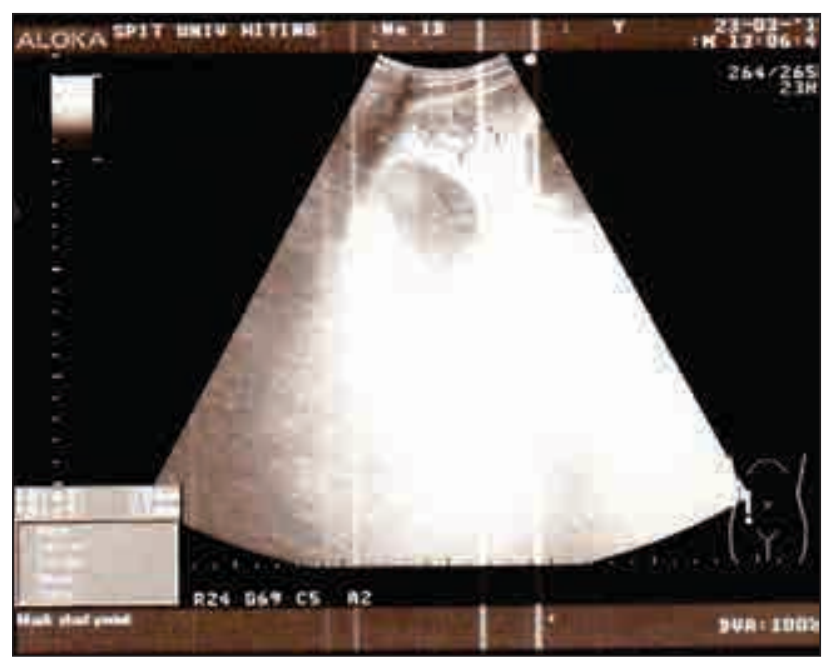

FIGURA 1. Aspect ecografic. 2 imagini cu aspect „în cocardă“, cu lizereu transsonic periferic şi zonă centrală neomogenă, având diametre maxime de 3,1 cm şi, respectiv, $1,8 \mathrm{~cm}$, situate în segmentul VII hepatic.

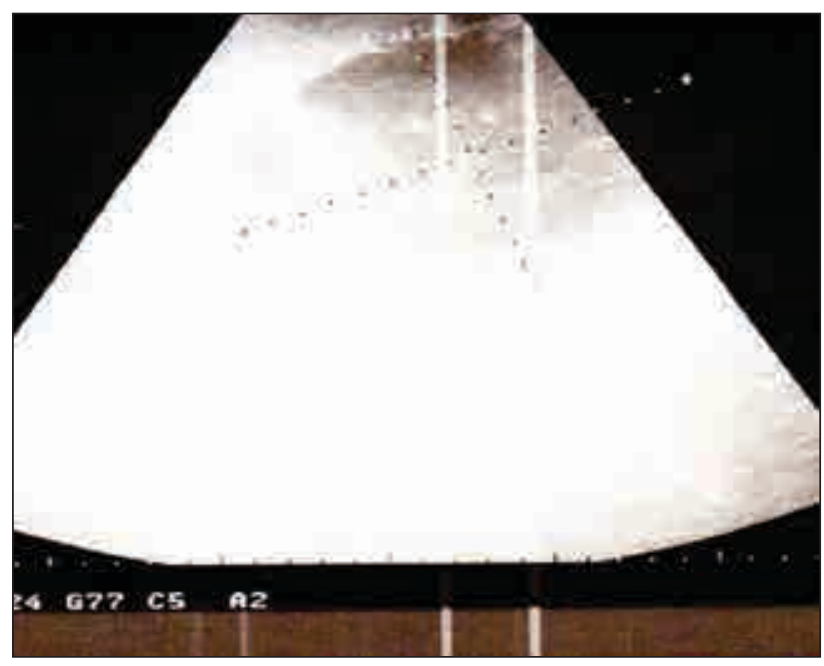

FIGURA 2. Segmentul VI este ocupat în totalitate de o formațiune tumorală macrochistică, aceasta având perete îngroşat pseudoparenchimatos, hipoecogen, neomogen, cu aspect burjonat şi grosime maximă de 3 $\mathrm{cm}$, cu septuri hiperecogene neregulate, pe alocuri posibil vascularizate 


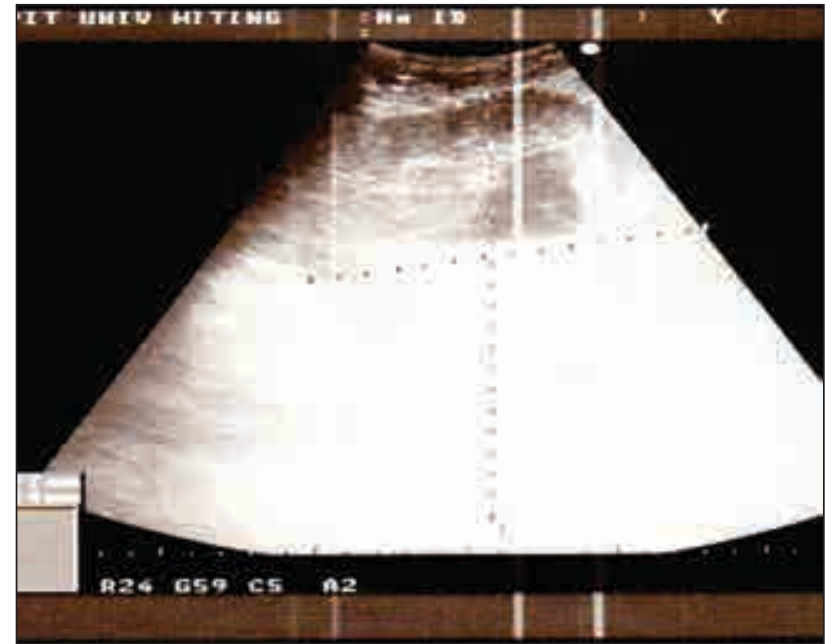

FIGURA 3. Aspect ecografic. La nivelul lobului stâng şi al hemiabdomenului stâng, până în fosa iliacă stângă, se vizualizează o formațiune transsonică, cu perete hipohiperecogen, neomogen, burjonat circumferențial, cu grosime maximă a peretelui de $8,3 \mathrm{~cm}$, prezentând conținut lichidian neomogen cu multiple ecouri ecogene ce flotează şi sunt mobile la compresie

Investigațiile endoscopice - endoscopia digestivă superioară şi inferioară - nu decelează modificări patologice, dar nu am putut investiga intestinul subțire.

Examinarea computer tomograf (CT) descrie la nivelul toracelui hemidiafragmul drept ascensionat, fără mase tumorale mediastinale sau intraparenchimatoase pulmonare, arborizaţia bronşică şi vasculară au distribuție si calibru normale. Ficatul este mărit de volum prin prezența de numeroase imagini chistice cu dimensiuni cuprinse între $1 \mathrm{~cm}$ şi $18 \mathrm{~cm}$, chisturile au contur net, dar pereții interiori au grosime inegală şi priză de contrast neomogenă (Figura 4). Pe secțiunile transversale, apar trei calcificări parenchimatoase în lobul hepatic drept, cea mai mare $14 \mathrm{~mm}$, cea mai mică $2-3 \mathrm{~mm}$, două dintre ele fiind tangente la peretele chistic.

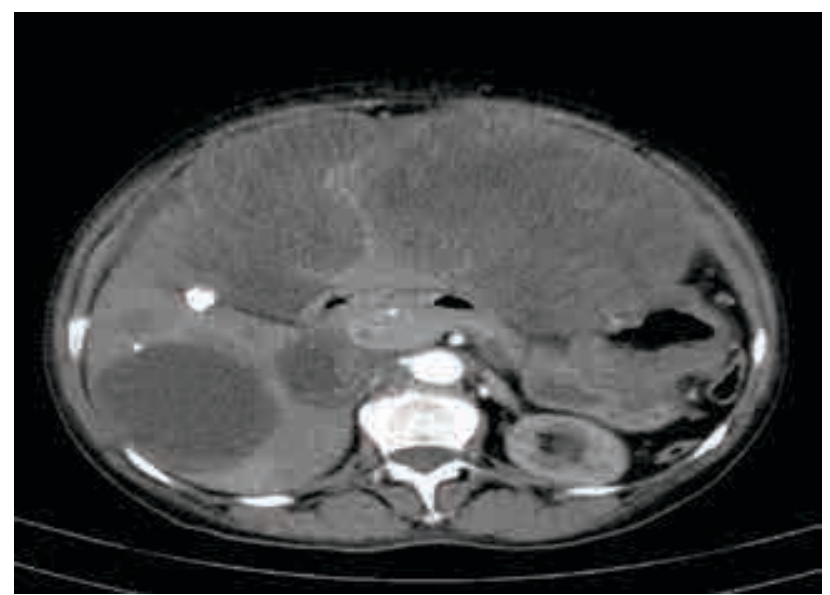

FIGURA 4. Formațiuni tumorale hepatice cu aspect chistic, pereți de grosime inegală şi priză de contrast neomogenă (aspect CT)
Două dintre cele mai voluminoase formațiuni sunt dezvoltate la nivelul segmentului IVB şi III şi ocupă aproape în întregime cavitatea peritoneală (Figura 5). Colecistul nu poate fi vizualizat, fiind probabil comprimat de formaţiunea învecinată şi se descrie o lamă de fluid periepatic şi hepatodiafragmatic cu grosime inegală cuprinsă între 1 şi 3 $\mathrm{cm}$.
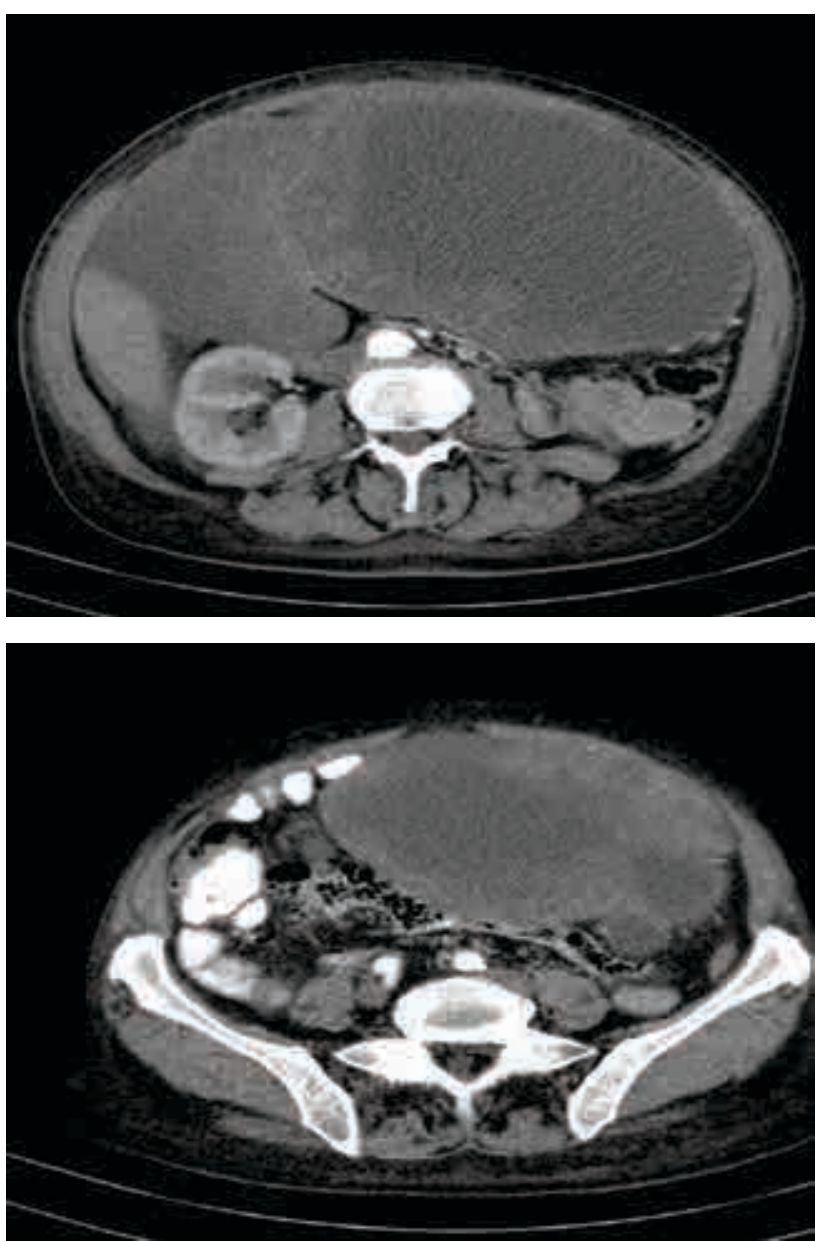

FIGURA 5. Polul inferior al formațiunii chistice din lobul stâng ajunge până în pelvis (14/18/18,5cm) şi dislocă posterior colonul transvers şi intestinul subțire spre fosa iliacă dreaptă (aspect CT)

După echilibrare hidroelectrolitică şi corectarea anemiei, se decide intervenția chirurgicală, scopul acesteia fiind stabilirea diagnosticului de certitudine şi tumorectomia reducțională. A 5-a zi de la internare, se practică laparotomie exploratorie prin incizie mediană xifopubiană, care pune în evidență lichid de ascită limpede în cantitate moderată aproximativ 2 litri, formațiuni tumorale hepatice care, practic, înlocuiesc ambii lobi, determinând formarea de cavități chistice gigante, cea de la nivelul lobului stâng coborând până în fosa iliacă stângă; parenchimul hepatic restant nu se vizualizează, ci doar se evidenţiază palpatoriu în periferia segmentelor VI-VII, ligamentul rotund al ficatului 
fiind, de asemenea, infiltrat tumoral (vezi Figurile $6,7)$.

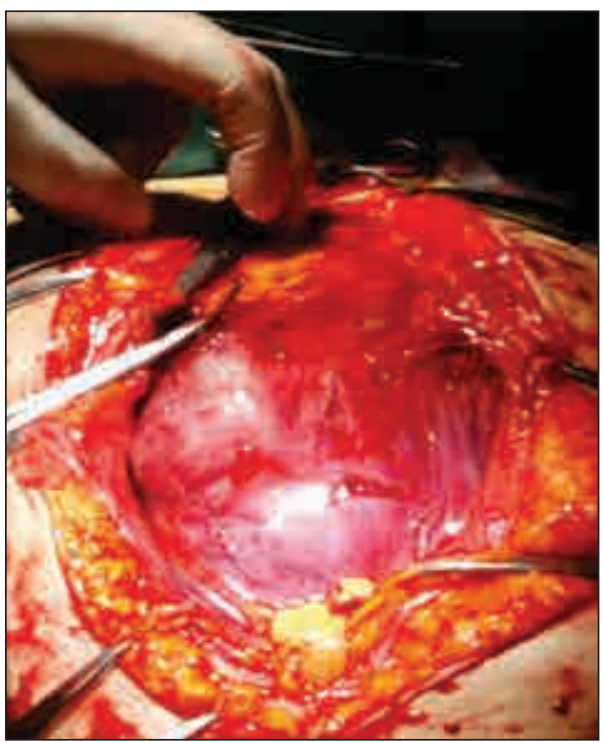

FIGURA 6. Tumoră hepatică gigantă aparținând ambilor lobi hepatici şi care infiltrează ligamentul rotund al ficatului (aspect intraoperator)

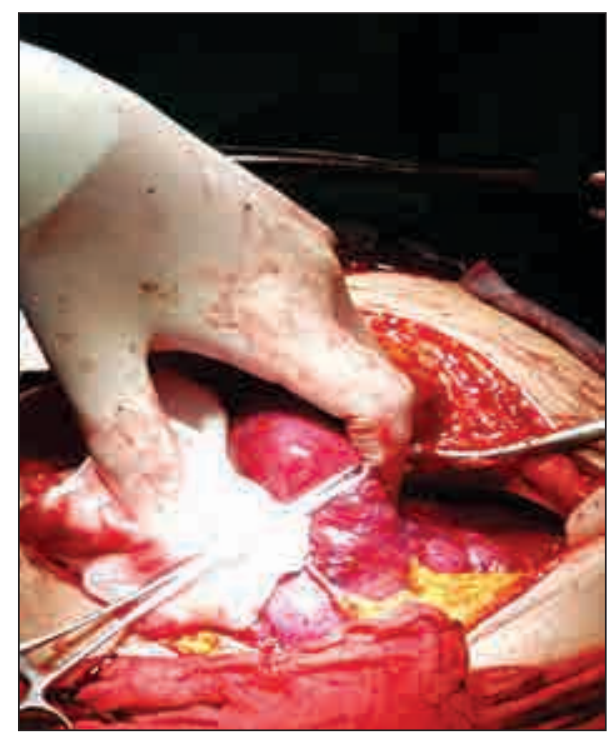

FIGURA 7. Formațiune tumorală chistică dezvoltată de la nivelul lobului stâng hepatic care coboară până la nivelul fosei iliace stângi şi dislocă masa intestinală spre partea dreaptă a abdomenului (aspect intraoperator)

Se practică biopsie excizională prin recoltarea de fragmente multiple de $1-2 \mathrm{~cm}$ de la nivelul formațiunii tumorale din lobul hepatic drept. Se incizează şi se evacuează tumora chistică dezvoltată la nivelul lobului hepatic stâng, cu evacuarea a 500 ml lichid limpede şi se realizează o reducție tumorală. Sângerarea este abundentă, hemostaza fiind foarte dificilă, posibilă doar prin compresie şi aplicare de bureți hemostatici (Figura 8).

Evoluția postoperatorie este iniţial trenantă, cu pierderi semnificative de lichid de ascită cu aspect hemoragic prin tuburile de dren peritoneale şi ne- cesitatea de a administra multiple transfuzii de masă eritrocitară. Externarea pacientei se face după 30 de zile de internare, cu plaga vindecată, tranzit intestinal prezent, alimentație orală, dar cu un drenaj peritoneal persistent de $500 \mathrm{ml} / \mathrm{zi}$ cu aspect ascitic.
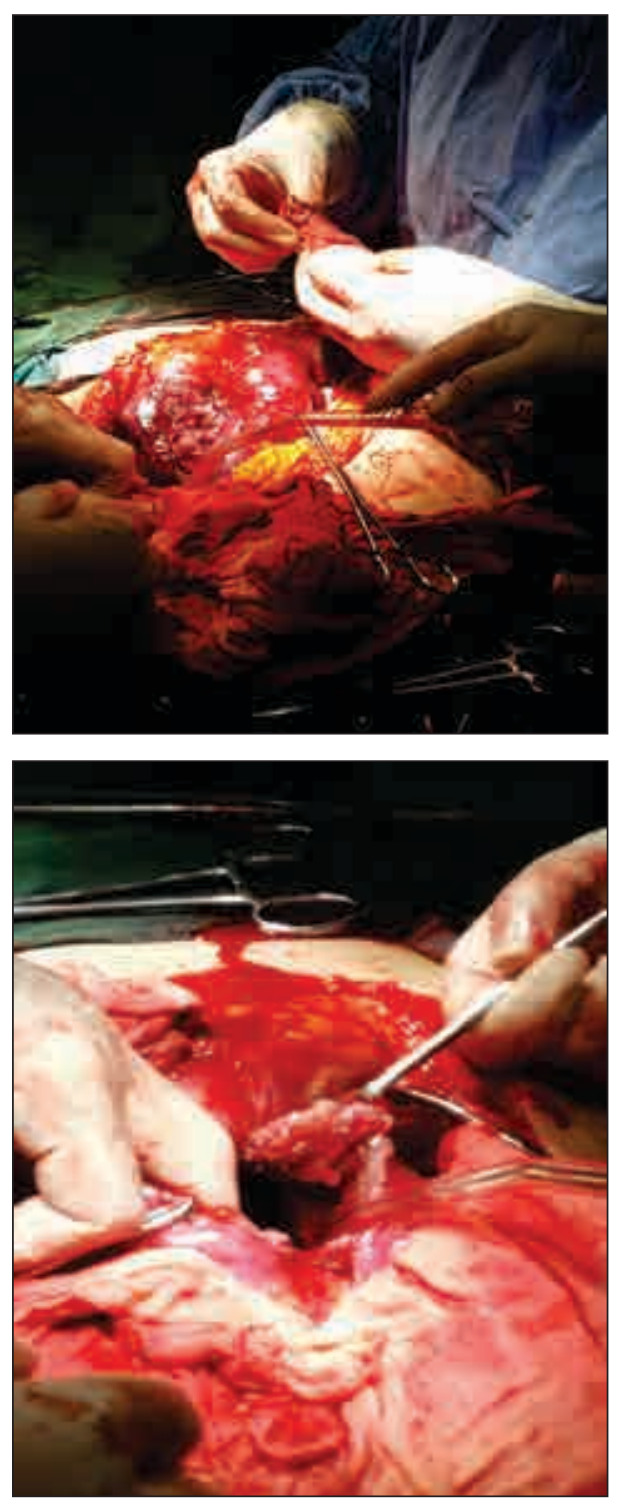

FIGURA 8. Tumora are aspect encefaloid, este extrem de friabilă, aderentă la masa intestinală, având parcelar aspect gelatinos, alternând cu travee fibroase şi formațiuni chistice cu conținut limpede (aspect intraoperator)

Examenul anatomopatologic descrie fragmente de proliferare tumorală alcătuite din celule fusiforme cu citoplasma vacuolară clară, nuclei ovalari, relativ uniformi, tahicromi/vacuolizati, cu nucleoli greu vizibili, limite celulare indistincte dispuse în jurul unor vase ectaziate cu perete subțire, cu activitate mitotică redusă -3 mitoze/50 HPF, concluziile studiului histopatologic fiind proliferare tumorală cu celulă clară de origine mezenchimală de tip GIST. 
Pentru a stabili diagnosticul de certitudine, examenul de imunohistochimie testează fragmentele tumorale pentru un număr relativ mare de imunomarkeri, rezultatele obținute fiind următoarele:

- CD117 - pozitiv în celulele tumorale;

- Vimentina - pozitiv în celulele tumorale;

- Actina - negativ în celulele tumorale; pozitiv în vase;

- PDGFR-alfa - pozitiv în celulele tumorale;

- CD34 - pozitiv în celulele tumorale;

- S100 - negativ;

- DOG1 - pozitiv în celulele tumorale;

- Ki67 - pozitiv, cu index de proliferare $25 \%$ in celulele tumorale.

Concluzia testelor imunohistochimice este de tumoră stromală gastrointestinală (GIST) malignă hepatică.

Se instituie tratament cu Imatinib (Glivec) 400 $\mathrm{mg}-2 \mathrm{tb} / \mathrm{zi}$, cu ameliorarea rapidă a stării generale, scăderea drenajului la $50 \mathrm{ml} / 24 \mathrm{~h}$, concomitent cu scăderea volumului abdominal şi scoaterea tuburilor de dren la aproximativ o lună de la debutul terapiei. Precizăm că terapia este bine tolerată de pacientă şi a fost continuă în cele 18 luni de monitorizare postoperatorie, pacienta supraviețuind până la această dată.

Controalele imagistice la 6 luni şi, respectiv, 12 luni relevă un răspuns parțial la terapia cu inhibitori de tirozinkinază conform criteriilor Choi (9), cu reducerea dimensiunilor formațiunilor tumorale hepatice şi scăderea densității acestora, aspecte mai evidente la un an de terapie (Figura 9).

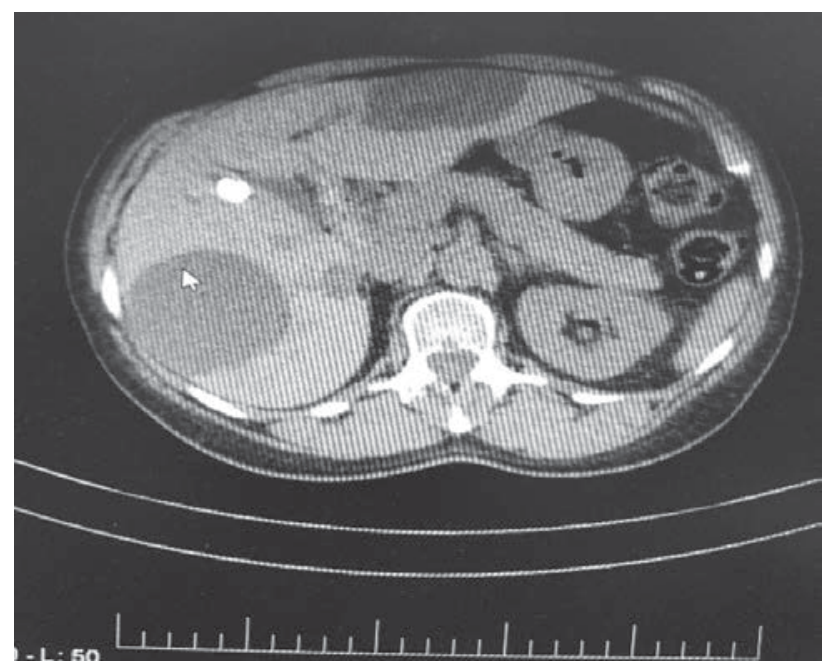

FIGURA 9. Aspect CT la 1 an de tratament cu TKI

La un an de tratament, se mențin dimensiuni crescute ale ficatului, procesele tumorale chistice având dimensiuni cuprinse între 1,5 şi $7,8 \mathrm{~cm}$. în diametrul maxim, densităţi de până la $16 \mathrm{UH}$, structură omogenă sau neomogenă, limite clare. În lobul drept hepatic, sunt vizibile 17 formaţiuni tumorale, iar cea mai voluminoasă situată între segmentele IV şi VII măsoară $7,4 / 7,8 \mathrm{~cm}$. În lobul hepatic stâng, sunt vizibile 3 leziuni, cea mai mare are 2,4/6,8 cm (Figura 10). Cel mai recent control radiologic, din 2020, la distanţă de 3 ani şi jumătate de la intervenția chirurgicală, relevă nu doar o involuție clară a formațiunii tumorale cu localizare hepatică, dar şi absenţa determinărilor secundare suplimentare (Figura 11).

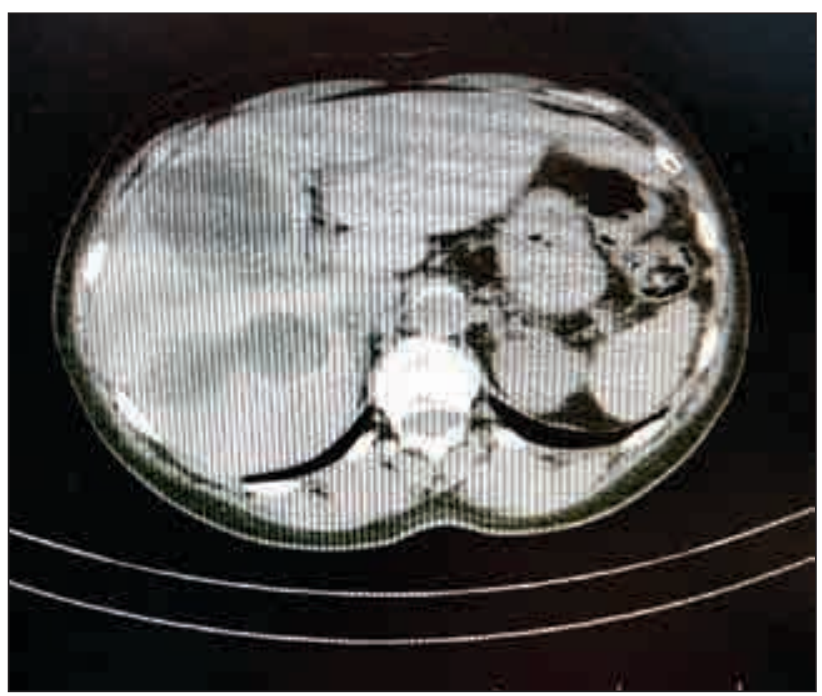

FIGURA 10. Aspect CT la 1 an de tratament cu TKI

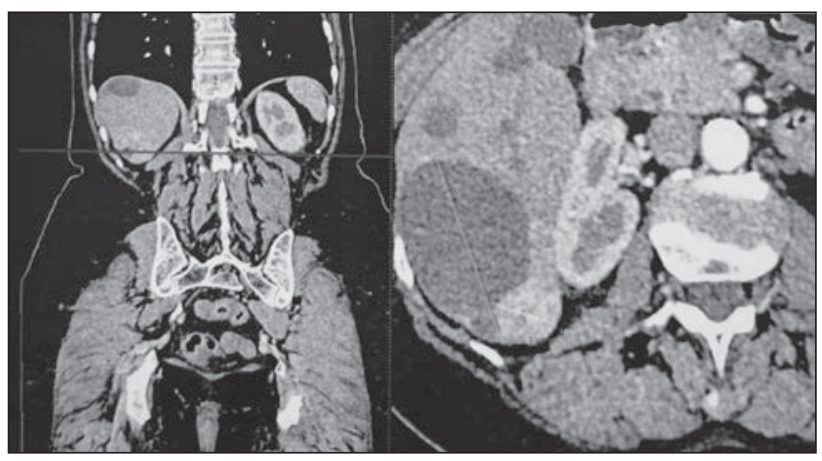

FIGURA 11. Aspectul CT la 3 ani şi jumătate postoperator, sub tratament cu TKI

\section{DISCUȚII}

Semnele şi simptomele au fost nespecifice, fapt concordant cu literatura de specialitate care raportează că simptomele asociate cu tumorile stromale gastrointestinale primare sunt, de obicei, vagi şi nespecifice şi depind de localizarea şi dimensiunea tumorii primare, procentul cazurilor cu suferință nespecifică ajungând până la $70 \%$.

Rolul investigațiilor imagistice pentru identificarea tumorii primare, stadializarea bolii şi pentru urmărirea evoluției bolii este binecunoscut, dar trebuie să precizăm rolul esențial pe care îl are în evaluarea răspunsului la terapia monogenică şi 
conducerea tratamentului. Computer tomografia (şi, mai rar, din cauza costurilor semnificativ mai mari, rezonanța magnetică nucleară) este investigația imagistică standard pentru monitorizarea răspunsului la terapia cu inhibitori de tirozinkinază (TKI). Toate studiile imagistice trebuie însă prezentate într-un mod standardizat şi rezultatele raportate conform criteriilor CT descrise de Choi (criterii RECIST modificate) de evaluare a răspunsului la tratament (tabelul 1) (9).

TABEL 1. Evaluarea răspunsului la tratament (9)

\begin{tabular}{|c|c|}
\hline $\begin{array}{l}\text { TIPUL DE } \\
\text { RĂSPUNS LA } \\
\text { TRATAMENT }\end{array}$ & $\begin{array}{l}\text { CRITERII CT DE EVALUARE A RĂSPUNSLUI } \\
\text { LA TRATAMENTUL CU TKI (după Choi H. } \\
\text { și colab) }\end{array}$ \\
\hline $\begin{array}{l}\text { Răspuns complet } \\
\text { CR - Complet } \\
\text { Response }\end{array}$ & $\begin{array}{l}\text { - Fără leziuni reziduale în toate leziunile } \\
\text { țintă } \\
\text { - Fără leziuni nou apărute }\end{array}$ \\
\hline $\begin{array}{l}\text { Răspuns parțial } \\
\text { PR - P } \\
\text { Response }\end{array}$ & $\begin{array}{l}\text { - O scădere de cel puțin } 10 \% \text { SLD sau } \\
\text { - O scădere mai mare de } 15 \% \text { a densității } \\
\text { tumorale (HU) } \\
\text { - Fără leziuni nou apărute } \\
\text { - Fără progresie evidentă a bolii } \\
\text { nonmăsurabile }\end{array}$ \\
\hline $\begin{array}{l}\text { Boală Stabilă } \\
\text { SD - Stable } \\
\text { Disease }\end{array}$ & $\begin{array}{l}\text { - Orice situațtie care nu poate } \\
\text { considerată CR, PR sau PD } \\
\text { - Fără simptomatologie evidentă care } \\
\text { poate atribuită progresiei tumorale }\end{array}$ \\
\hline $\begin{array}{l}\text { Boală progresivă } \\
\text { PD - Progressive } \\
\text { Disease }\end{array}$ & $\begin{array}{l}\text { - Creștere cu cel puțin } 10 \% \text { a SLD și lipsa } \\
\text { criteriilor pentru PR în ceea ce privește } \\
\text { dimensiunea tumorală sau densitatea } \\
\text { tumorală } \\
\text { - Apariția uneia sau mai multor leziuni } \\
\text { noi și/sau } \\
\text { - Apariția de noi noduli intratumorali sau } \\
\text { creșterea în dimensiuni a celor existenți }\end{array}$ \\
\hline
\end{tabular}

$C R$ : complet response (răspuns complet). PR: partial response (răspuns parțial). SD: stable disease (boală stabilă). PD: progressive disease (boală progresivă). SLD: the sum of longest diameters of target lesions (Suma celor mai mari diametre ale leziunilor țintă) - așa cum a fost definită de criteriile RECIST. RECIST: Response evaluation criteria in solid tumors (Criterii de răspuns la tratament în tumorile solide)

Esențială pentru inițierea şi conducerea terapiei cu inhibitori de tirozinkinază (TKI) este aprecierea agresivității tumorale. Dimensiunea tumorii şi indicele mitotic rămân principalele variabile utilizate în sistemele de stratificare a riscului şi au fost utilizate pentru prima dată de Fletcher şi colab. în Clasificarea NIH (National Institute of Health) din 2002 (10). Versiunea revizuită a sistemului de stratificare a riscului NIH prin includerea unor factori suplimentari de prognostic, cum ar fi localizarea tumorii şi ruptura capsulară, a fost propusă de Joensuu şi colab. şi denumită Clasificarea NIH modificată, disponibilă din 2008 (tabelul 2) (11).

De-a lungul timpului, au fost propuse şi alte sisteme de apreciere a riscului de progresie tumorală, dar care nu sunt folosite pe scară largă, principalul dezavantaj fiind complexitatea, ceea ce reduce sensibilitatea în aprecierea prognosticului.
TABEL 2. Criteriile NIH modificate (11)

\begin{tabular}{|c|c|c|c|}
\hline $\begin{array}{l}\text { CATEGORIA } \\
\text { DE RISC }\end{array}$ & $\begin{array}{l}\text { DIMENSIUNEA } \\
\text { TUMORII } \\
(\mathrm{cm})\end{array}$ & $\begin{array}{c}\text { INDICELE } \\
\text { MITOTIC } \\
\text { (per } 50 \text { HPF) }\end{array}$ & $\begin{array}{c}\text { LOCALIZAREA } \\
\text { TUMORII } \\
\text { PRIMARE }\end{array}$ \\
\hline $\begin{array}{l}\text { Risc foarte } \\
\text { scăzut }\end{array}$ & $\leq 2 \mathrm{~cm}$ & $\leq 5$ & Oricare \\
\hline Risc scăzut & $2,1-5,0 \mathrm{~cm}$ & $\leq 5$ & Oricare \\
\hline \multirow{3}{*}{$\begin{array}{l}\text { Risc } \\
\text { intermediar }\end{array}$} & $2,1-5,0 \mathrm{~cm}$ & $>5$ & Gastric \\
\hline & $<5,0 \mathrm{~cm}$ & $6-10$ & Oricare \\
\hline & $5,1-10,0 \mathrm{~cm}$ & $\leq 5$ & Gastric \\
\hline \multirow[t]{6}{*}{ Risc înalt } & Oricare & Oricare & $\begin{array}{l}\text { Oricare cu } \\
\text { ruptură } \\
\text { tumorală } \\
\end{array}$ \\
\hline & $>10,0 \mathrm{~cm}$ & Oricare & Oricare \\
\hline & Oricare & $>10$ & Oricare \\
\hline & $>5,0 \mathrm{~cm}$ & $>5$ & Oricare \\
\hline & $2,1-5,0 \mathrm{~cm}$ & $>5$ & Nongastric \\
\hline & $5,1-10,0 \mathrm{~cm}$ & $\leq 5$ & Nongastric \\
\hline
\end{tabular}

HPF: High power field

Conform criteriilor NIH modificate, tumora EGIST prezentată se încadrează în categoria de risc înalt, având 3 din cele 4 criterii de gravitate şi anume dimensiunea $>5 \mathrm{~cm}$, localizarea nongastrică şi efracția capsulei în timpul intervenției chirurgicale, în contrast $\mathrm{cu}$ indicele mitotic de 3 mitoze/50HPF (indicele mitotic determinat în zona cu cea mai mare activitate proliferativă - număr de mitoze în 50 câmpuri de mare putere HPF, high power fields - reprezentând aproximativ $5 \mathrm{~mm}^{2}$ de tesut).

Examenul histopatologic standard a descris structura histologică cel mai frecvent întâlnită GIST cu celule fusiforme, dar diagnosticul de certitudine a fost stabilit de examenul imunohistochimic, care a depistat un număr mare de imunomarkeri specifici GIST, şi anume CD117, CD34, PDGFRA şi DOG1. De remarcat că literatura de specialitate a ultimilor ani a demonstrat că, deşi se considera CD117 ca fiind specific tumorilor de tip stromal de la nivelul tubului digestiv, totuşi, DOG1 are specificitatea cea mai mare (8). Analiza mutaţională lipseşte din bateria de teste, dar, în acest caz particular, nu este absolut necesară deoarece pacienta a răspuns la tratamentul adjuvant şi nu a dezvoltat rezistență secundară la Imatinib.

Tratamentul chirurgical a fost limitat la reducția tumorală, dar a avut importanță fundamentală pentru stabilirea diagnosticul de certitudine. Studiile cu număr mare de pacienți au demonstrat că rezecția $\mathrm{R} 1$ poate fi utilizată în cazurile în care rezecția cu margini microscopic negative $\mathrm{R} 0 \mathrm{nu}$ este posibilă, chirurgia citoreductivă având beneficii pentru supraviețuire, beneficii însă neevaluate în mod clar.

Încadrarea tumorii în grupa de risc înalt şi tratamentul chirurgical care a reuşit doar reducția tu- 
morală cu cantitate mare de țesut tumoral restant determină necesitatea terapiei adjuvante cu TKI Imatinib pe termen nedefinit, prognosticul fiind rezervat.

Supraviețuirea pacienţilor diagnosticaţi şi trataţi pentru tumori stromale gastrointestinale este dificil de estimat ca urmare a eterogenității acestora, factorii care influențează supraviețuirea globală (overall survival - OS) şi, implicit, supraviețuirea fără recidivă (releapse free survival - RFS) fiind modalitatea de prezentare (boala secundară sau boala primară avansată loco-regional sau metastatică), localizarea (nongastrică), dimensiunea tumorii (diametrul maxim $>10 \mathrm{~cm}$ ), indicele mitotic (indicele mitotic $>5$ mitoze/50 HPF), dar şi inoperabilitatea. În acelaşi timp, vârsta, sexul şi tipul rezecției chirurgicale (margini de rezecție invadate microscopic sau microscopic negative) sau markerii imunohistochimici nu influențează prognosticul pe termen lung.

\section{BIBLIOGRAFIE}

1. Mazur MT, Clark HB. Gastric stromal tumors. Reappraisal of histogenesis. Am J Surg Pathol. 1983;7(6):507-19.

2. Kindblom LG, Remotti HE, Aldenborg F, Meis-Kindblom JM. Gastrointestinal pacemaker cell tumor (GIPACT): gastrointestinal stromal tumors show phenotypic characteristics of the interstitial cells of Cajal. The American Journal of Pathology. 1998;152(5):1259-69.

3. Patil DT, Rubin BP. Gastrointestinal Stromal Tumor: Advances in Diagnosis and Management. Archives of Pathology \& Laboratory Medicine. 2011;135(10):1298-310.

4. McCarter MD, Antonescu CR, Ballman KV, Maki RG, Pisters PW, Demetri GD, et al. Microscopically positive margins for primary gastrointestinal stromal tumors: analysis of risk factors and tumor recurrence. Journal of the American College of Surgeons. 2012;215(1):53-60.

5. Jiang Q, Lu W. Extragastrointestinal Stromal Tumors (EGISTs).

Retroperitoneal Tumors - Clinical Management. Springer Science+Business Media B.V. 2018;203-8

\section{CONCLUZII}

În cazul pacientei prezentate, deşi prognosticul iniţial a fost nefavorabil, supraviețuirea este nesperat de lungă probabil ca urmare a structurii histologice favorabile, a indicelui mitotic scăzut, a răspunsului spectaculos la terapia cu Imatinib fără instalarea rezistenței secundare şi, nu în ultimul rând, a complianței la tratamentul de lungă durată.

De remarcat în legătură cu acest caz este faptul că, deşi s-au utilizat examene imagistice performante şi s-a efectuat laparotomia exploratorie, nu a putut fi stabilită originea GIST în tractul gastrointestinal. Examenul imunohistochimic susţine originea hepatică a acesteia, deşi sunt autori care contestă această posibilă apartenență, afirmând că tumorile dezvoltate în organele parenchimatoase (ficat, pancreas, prostată) sunt leziuni metastatice apărute prin extensie directă de la GIST provenite din organele digestive cavitare.

Conflict of interest: none declared Financial support: none declared

6. Miettinen M, Lasota J. Gastrointestinal stromal tumors: pathology and prognosis at different sites. Semin Diagn Pathol. 2006;23.

7. Miettinen M, Lasota J. Gastrointestinal Stromal Tumors. Gastroenterology Clinics of North America. 2013;42(2):399-415.

8. Novelli M, Rossi S, Rodriguez-Justo M, Taniere P, Seddon B, Toffolatti L, et al. DOG1 and CD117 are the antibodies of choice in the diagnosis of gastrointestinal stromal tumours. Histopathology. 2010;57(2):259-70.

9. Choi H. Imaging modalities of gastrointestinal stromal tumors. J Surg Oncol. 2011;104(8):907-14.

10. Fletcher CD, Berman JJ, Corless C, Gorstein F, Lasota J, Longley $\mathrm{BJ}$, et al. Diagnosis of gastrointestinal stromal tumors: A consensus approach. Human Pathology. 2002;33(5):459-65.

11. Joensuu H. Risk stratification of patients diagnosed with gastrointestinal stromal tumor. Human Pathology. 2008; 39(10):1411-9. 